\title{
Corrective Feedback in L2 Writing: Theoretical Perspectives, Empirical Insights, and Future Directions
}

\author{
CATHERINE VAN BEUNINGEN \\ University of Amsterdam
}

Received: 8 November 2010 Accepted: 29 November 2010

\begin{abstract}
The role of (written) corrective feedback (CF) in the process of acquiring a second language (L2) has been an issue of considerable controversy among theorists and researchers alike. Although CF is a widely applied pedagogical tool and its use finds support in SLA theory, practical and theoretical objections to its usefulness have been raised (e.g. Truscott, 1996; 1999; 2004; 2007; 2009). In the present paper, I start by summarizing the theoretical arguments underpinning the use of CF in L2 classrooms. Subsequently, the objections raised against error correction are reviewed, and some controversies concerning different CF methodologies and error types are discussed. Next, the paper provides a critical summary of the findings produced by empirical work to date, and sketches out some of the issues that need to be attended to in future research. Based on the available empirical evidence, I conclude that, by offering learners opportunities to notice the gaps in their developing L2 systems, test interlanguage hypotheses, and engage in metalinguistic reflection, written CF has the ability to foster SLA and to lead to accuracy development.
\end{abstract}

\section{KEYWORDS:}

written corrective feedback, error correction, second language writing, accuracy development, second language acquisition

\section{RESUMEN}

El papel que la corrección de trabajos escritos (written corrective feedback) (CF) desempeña en el proceso de adquisición de una segunda lengua (L2) ha sido objeto de controversia tanto desde el punto de vista teórico como empírico. Aunque el empleo de este tipo de corrección como herramienta pedagógica está muy extendido, y su utilización se apoya en teorías de adquisición de segundas lenguas, su utilidad ha sido cuestionada tanto desde el punto de vista práctico como teórico (Truscott, 1996; 1999; 2004; 2007; 2009). En el presente artículo se incluye, primero, un resumen de los argumentos teóricos que apoyan el uso de la corrección de trabajos escritos en el aula. Seguidamente se presenta una revisión de las objeciones planteadas en contra de su utilización y una discusión de algunas de las principales controversias que han surgido en torno a las distintas metodologías de corrección empleadas y a las tipologías de errores establecidas. Finalmente, se incluye un resumen crítico de los resultados obtenidos en la investigación empírica hasta la fecha y se plantean algunos aspectos que han de tenerse en cuenta en futuras investigaciones. Teniendo en cuenta la evidencia empírica existente, se concluye que la corrección de trabajos escritos ofrece a los aprendices oportunidades de detectar problemas en su interlengua, comprobar hipótesis sobre la L2 e involucrarse en procesos de reflexión metalingüística, y que, por tanto, tiene el potencial de facilitar la adquisición de segundas lenguas y de fomentar el desarrollo de la precisión lingüística (accuracy).

\section{PALABRAS CLAVE:}

corrección de trabajos escritos, corrección de errores, escritura en segundas lenguas, desarrollo de la corrección lingüística, adquisición de segundas lenguas

\footnotetext{
*Address for correspondence: Catherine van Beuningen, University of Amsterdam, Spuistraat 134, 1012 VB, Amsterdam, The Netherlands Tel.: +31 (0)20 5254658 E-mail: C.G.vanBeuningen@uva.nl
} 


\section{INTRODUCTION}

When reviewing their students' texts, L2 (writing) teachers give feedback on a wide range of issues. They might address the text's content, the way in which its ideas are presented and organized, the appropriateness of the vocabulary that is used, and so on. The type of feedback that has received most of researchers' attention, however, is feedback on linguistic errors. Such responses to L2 learners' non-targetlike production have been commonly referred to as instances of corrective feedback (CF) or error correction.

The numerous studies investigating the usefulness of CF are situated at the intersections of two academic disciplines, both with their own theoretical and methodological orientations (e.g. Ellis, 2010; Ferris, 2010; Manchón, in press; Santos, López-Serrano, \& Manchón, 2010; Sheen, 2010a): the field of L2 writing and the domain of second language acquisition (SLA).

Researchers in the field of L2 writing have been mainly interested in the question if and how CF can help students to become more able and self-employed writers (e.g. Chandler, 2003; Ferris, 2006). The predominant focus of studies within this strand of research has been on exploring the role of feedback in the process of developing learners' editing and revision skills. This perspective has been referred to as the learning-to-write dimension of L2 writing (see e.g. Leki, Cumming, \& Silva, 2008 for a review).

Currently, however, the research focus seems to be shifting towards the potential of written CF in aiding learners' interlanguage development. Arising from a writing-to-learn agenda (e.g. Harklau, 2002; Manchón, 2009; in press; Ortega, 2009; Santos et al., 2010), and based within a psycholinguistic and cognitive SLA framework, recent studies have been investigating if receiving and processing written CF can lead to L2 learning (e.g. Bitchener \& Knoch, 2010a; Ellis, Sheen, Murakami, \& Takashima, 2008; Sheen, 2007). Inspired by oral CF studies, these investigations were tightly controlled in their methodological set-up, and measured the effects of CF by comparing learners' accuracy performance on pre-tests and (delayed) post-tests. The present paper focuses on this type of SLA oriented CF research.

Even though a number of theoretical SLA insights would predict that written CF can foster L2 development, and despite the fact that the efficacy of oral CF is well documented (see for example meta-analyses by Li, 2010, Lyster \& Saito, 2010, and Mackey \& Goo, 2007), the usefulness of written error correction has been and remains a topic of considerable debate (see particularly Ferris, 1999; 2004; Truscott, 1996; 1999; 2007; Truscott \& Hsu, 2008). This paper intends to review the theoretical arguments underpinning the use of CF in L2 instruction, the objections raised against CF, and the empirical evidence concerning the value of written CF to the SLA process. In the final part, I will synthesize the major research findings to date and point out some directions for future research. 


\section{THEORETICAL FOUNDATIONS OF THE USE OF CF IN L2 INSTRUCTION}

The rationale for expecting that error correction can be beneficial to language learning rests on various theoretical grounds. Without claiming to provide a comprehensive overview of related theoretical notions and insights, this section will summarize some of the theoretical foundations of the use of CF in L2 classrooms.

\subsection{L1 and L2 Acquisition: Different Processes, Different Approaches}

Since the early 1970's a communicative approach to language teaching has been dominating the field of L2 instruction. The communicative paradigm was initiated as a movement away from traditional, structural methods of L2 pedagogy, which focused on teaching isolated linguistic features and grammar rules. Inspired by theories of communicative competence (e.g. Canale \& Swain, 1980; Hymes, 1971), communicative approaches aim at developing learners' ability to use the L2 in realistic, meaningful communication. Key ingredients of this approach are providing learners with abundant comprehensible input (e.g. Krashen, 1981; 1982; 1985), and creating opportunities to engage in meaningful language use. In doing so, communicative approaches construct an environment that promotes naturalistic acquisitional processes, such as implicit and incidental learning (e.g. Krashen \& Terrell, 1983; Long, 1985; Skehan, 1998).

Based on the nativist idea that L1 and L2 acquisition are much alike, some researchers have been advocating a fully naturalistic approach to L2 teaching (e.g. Krashen \& Terrell, 1983). Having access to ample comprehensible input was thought to be the necessary and sufficient condition for SLA. Learners were expected to comprehend the available input by inferring its meaning on the basis of linguistic information that is embedded in the communicative context. L2 grammatical competence was believed to emerge automatically, without any need for negative evidence (e.g. Krashen, 1981; 1982; 1985; Schwartz, 1993).

However, it seems fair to state that nowadays the consensus within the field of SLA is that L1 and L2 acquisition are not instances of the same phenomenon; the cognitive processes involved in L1 and L2 acquisition do not fully overlap (Doughty, 2003). Research investigating L2 acquisition in naturalistic settings provided support for this hypothesized difference. Studies in the context of French immersion classrooms in Canada, for instance, have found that learners failed to acquire a native-like grammatical competence despite of the continuous exposure and practice opportunity the immersion context provided for. Whereas learners were typically shown to develop native-like perceptive skills and fluency, they failed to reach a target-like level of accuracy (e.g. Swain, 1991 or see e.g. Lyster, 2007 for a review). Findings as these suggest that, however necessary for SLA, abundant comprehensible input is not a sufficient condition for developing a near-native level of 
accuracy. Révész (2007) clarified that comprehension and acquisition are not just two sides of the same coin and that "comprehension may occur in the absence of acquiring linguistic knowledge” (p. 5). It is quite possible for learners to grasp the meaning of a message by relying on contextual information and/or already acquired linguistic awareness. In doing so, they may totally circumvent processing the message’s morphosyntactic encoding.

Ample opportunity for language production does not guarantee learners to be pushed beyond strategic and semantic processing either (Révész, 2007). Even when producing output, L2 learners do not necessarily engage in (full) morphosyntactic processing. They are able to construct a message which is communicatively adequate even when formal accuracy is lacking, or as Skehan and Foster (2001) put it "language can work despite poor execution. Its meaning is recoverable even if its form is incorrect” (p. 183). Additionally, in total absence of consideration for L2 accuracy, learners might proceduralize such non-targetlike linguistic solutions to communicative problems, and premature fossilization of errors could be the result (e.g. Skehan \& Foster, 2001).

If one starts from the idea that a native-like proficiency on all possible levels, including accuracy, is the ultimate goal of L2 instruction, the conclusion should be that a fully meaning-based approach to L2 instruction does not suffice. Instead, some attention to linguistic form is necessary for learners to be able to progress towards well-formedness in their L2 (e.g. Ellis, 2005; Long, 2000; Long \& Robinson, 1998; Norris \& Ortega, 2000; Skehan \& Foster, 2001). Current communicative methodologies (e.g. task-based approaches, content-based approaches, language sensitive approaches to content teaching) indeed all incorporate some form of grammar instruction.

\subsection{CF as a Focus-on-Form Intervention}

As elucidated in the previous section, it is now widely accepted that effective L2 pedagogy should involve - at least at times - attention to linguistic form. Without it, L2 acquisition could be expected to be slower, more difficult, and less successful (Doughty, 2003). A pedagogical intervention that has received considerable attention and which has been advocated in the SLA field (see for example Norris \& Ortega, 2000 for a review) is Long's focus-on-form approach (Long 1991; 1996; 2000; Long \& Robinson, 1998). According to Long (2000) focus-on-form

involves briefly drawing students' attention to linguistic elements [...] in context as they arise incidentally in lessons whose overriding focus is on meaning or communication. The temporary shifts in focal attention are triggered by students' problems with comprehension or production (p. 185).

One of the most crucial characteristics of a focus-on-form intervention is that it is provided within a communicative context. The importance behind this is explained well by Lyster 
(2007) in terms of Segalowitz’s (1997; 2000) notion of transfer-appropriate learning. Lyster (2007) rephrased the essence of this concept by stating that “... the kind of cognitive processing that occurs while performing [language] learning tasks should ideally resemble the kind of processing involved during communicative language use” (p. 43). The drawback of decontextualized grammar teaching is that learners will have difficulty transferring the knowledge they have gained from isolated grammar lessons to actual language use in a communicative situation. The focus-on-form approach, on the other hand, caters for learning that is transfer-appropriate.

Whereas Long's definition implies that focus-on-form episodes are unplanned (i.e. incidental), other researchers (e.g. Doughty \& Williams, 1998; Ellis, Basturkmen, \& Loewen, 2002) have adopted a broader perspective on what can constitute a focus-on-form episode; in their view focus-on-form can be both planned and unplanned, and reactive as well as preemptive.

One of the pedagogical tools identified as a potential focus-on-form instrument is error correction (e.g. Ellis, 2005). CF is a reactive focus-on-form methodology with the specific value of inducing learners' attention to form in the context of performing a task in a personalized, individualized manner. It could be argued that CF on written output is especially promising as a focus-on-form intervention. Whereas oral feedback will inevitably interrupt the communicative flow, learners only have to deal with written feedback after meaning has been communicated (Polio, Fleck, \& Leder, 1998).

\subsection{CF as Noticing Facilitator}

A second fundamental motivation of the focus-on-form methodology - apart from Segalowitz's (1997; 2000) notion of transfer-appropriate learning - can be found in Schmidt's Noticing Hypothesis (Schmidt, 1990; 2001). The concept of noticing combines the two crucial cognitive linguistic notions of attention and awareness (Svalberg, 2007). The Noticing Hypothesis states that subliminal SLA is impossible, and that it is only through conscious attention that input can be converted into intake ${ }^{1}$. Schmidt thus argued that noticing is a necessary condition for language learning.

Another essential role associated with attention is its ability to make learners aware of "a mismatch or gap between what they can produce and what they need to produce, as well as between what they produce and what target language speakers produce” (Schmidt, 2001, p. 6). This concept has been commonly referred to as noticing the gap (e.g. Schmidt and Frota, 1986). Ellis (1995) used the term cognitive comparison rather than noticing the gap because, in his view, learners also need to notice when their output is the same as the input.

When conscious attention to linguistic form is considered facilitative to or even a prerequisite for interlanguage development, focus-on-form interventions such as CF can be expected to support the SLA process (e.g. DeKeyser, 1994; Han, 2002). As Hulstijn and 
Schmidt (1994) stated, they can be considered cognitive focusing devices for learner attention. In raising learners' awareness of certain linguistic features, CF enables learners to notice the gaps between their own interlanguage output and the target language input (i.e. the feedback provided). Subsequently, these noticing operations could prompt destabilization and restructuring of learners’ developing interlanguage grammar (e.g. Gass, 1997; Long, 1996).

Adams (2003) furthermore pointed at the advantage of written CF over orally provided feedback. Although both modalities provide learners with the opportunity of noticing mismatches between the target language and their interlanguage system, learners might not (always) be able to make the cognitive comparison in online oral language use. The classic psychological conception of attentional resources is that they are limited (Schmidt, 2001); when presented with an overwhelming number of stimuli at any given moment, the human brain might be unable to attend to them all due to a lack of available processing capacity (Al-Hejin, 2004). Being very demanding on learners' attentional resources, online language production and orally provided CF might produce such a cognitive overload. In writing, on the other hand, learners have enough time - and therefore cognitive resources - to compare their output with the CF they received, which increases the likelihood of learners noticing gaps in their interlanguage (e.g. Polio et al., 1998; Sheen, 2010a).

\subsection{Pushed Output and CF}

Krashen (1989) stated that output is nothing more than a product of already acquired L2 competence. Today however, drawing on Swain's (1985; 1995) Output Hypothesis, most SLA researchers acknowledge that learner output is a valuable source for acquisition (e.g. Ellis, 2003; 2005; Manchón, in press; Skehan, 1998). Swain argued that the importance of L2 output lies in the fact that output production pushes learners to process language more deeply (i.e. beyond semantic processing) and with more mental effort than is necessary during listening and reading.

Swain (1985; 1995) specified three specific functions of learner output ${ }^{2}$. Firstly, producing output allows learners to test hypotheses about the target language grammar. Secondly, it may trigger the type of meta-linguistic reflection that is beneficial to interlanguage development. Finally, output has the ability to promote noticing and to push learners' awareness of the gaps and problems in their interlanguage system.

Swain (1991) added that output by itself does not necessarily serve these functions, and recognized the importance of CF by stating that "if students are given insufficient feedback or no feedback regarding the extent to which their messages have successfully (accurately, appropriately, and coherently) been conveyed, output may not serve these roles” (p. 98). Likewise, other researchers (e.g. Han, 2002) have claimed that learners' output should be accompanied by $\mathrm{CF}$ in order to be beneficial to the language learning process: 
[W] hile the focus is on meaning, there is a limit to how much an L2 learner can introspect the sufficiency of his own linguistic resources. Also, even if the learner consciously recognizes at that point what he lacks, there is no guarantee, for various reasons, that he will subsequently be able to tune himself in for a solution in the future input, or even if he is, he may not be able to tell whether what he sees as the potential solution is actually the correct solution. Rather, external feedback [...], I shall argue, may significantly facilitate the fulfillment of the 'noticing' function (p. 18).

Again, it might be argued that the beneficial effects associated with written output and CF will outweigh those of oral language use and correction. The fact that, in writing, learners are not under such strict time constraints as in online oral language production, makes it more feasible that the beneficial roles of output production in combination with CF are actually realized.

\section{OBJECTIONS AGAINST THE USE OF CF IN L2 INSTRUCTION}

While the previous sections discussed why CF can be presumed to facilitate SLA, some researchers have stated error correction to be entirely unnecessary and ineffective, or even harmful (e.g. Krashen, 1985; Schwartz, 1993; Truscott, 1996). This claim relies on both practical and theoretical arguments. The practical doubts pertain to teachers' capacities in providing adequate and consistent feedback, and learners' ability and willingness to use the feedback effectively (Truscott, 1996). The theoretical case against error correction rests on the claim that CF overlooks important insights from SLA theory. The two main theoretical issues that informed the objections raised by CF opponents will be discussed here, namely the role of explicit L2 knowledge in the language learning process and Pienemann's (1989; 1998) Learnability Hypothesis. This section furthermore reviews the hypothesized detrimental sideeffects of CF.

\subsection{Implicit vs. Explicit L2 Knowledge}

An often addressed issue in the field of instructed SLA is the role of conscious grammar knowledge in becoming a proficient user of the L2. Conscious knowledge about the L2 grammatical system has been widely referred to as explicit or declarative knowledge, and opposed to implicit or procedural knowledge (e.g. Bialystok, 1994; DeKeyser, 1998; Krashen, 1981; see DeKeyser, 2003 for an extensive review). Explicit knowledge denotes a conscious awareness of grammatical rules and the appropriate meta-language for labeling and verbalizing this knowledge (Ellis, 2004). Implicit knowledge, on the other hand, is claimed to be unconscious, non-verbalizable, and rapidly and easily accessible during online language use. 
Currently, the assumption is that it is their implicit L2 knowledge that enables learners to communicate spontaneously and fluently ${ }^{3}$. How the type of explicit knowledge resulting from grammar instruction contributes to the SLA process, however, "has been and remains today one of the most controversial issues in language pedagogy” (Ellis, 2005, p. 214). Disagreements concern both the value of explicit knowledge in itself and the connection between explicit and implicit knowledge. This debate is important when exploring the effectiveness of error correction, because CF contestants (e.g. Krashen, 1982; Truscott, 1996) have stated that, if CF yields any L2 knowledge at all, this emerging knowledge could only be explicit in nature.

Opponents to the use of CF in L2 classrooms, such as Krashen (1982), claimed that the benefits of explicit knowledge as such to actual L2 performance are rather limited. In Krashen's view, learners can only use their explicit L2 knowledge during monitoring (i.e. editing of output after it has been initiated by the acquired system), and not in online language use. In exploring the effect of online planning time on learners' oral language performance, Yuan and Ellis (2003) found, however, that the available planning time improved the accuracy of learners' online production. This finding suggests that - if provided with enough time - learners are able to access their explicit knowledge online, and therefore the value of conscious L2 knowledge is not restricted to monitor use (Ellis, 2005).

Irrespective of the value of explicit knowledge as such, it may be the case that explicit knowledge aids the development of implicit knowledge. However, those opposing the effectiveness of CF adhere to the position that explicit and implicit knowledge systems are entirely distinct, without an interface connecting them. This view is strongly related to Krashen's (1981; 1982; 1985) proposed distinction between learning and acquisition. According to Krashen, acquisition of implicit knowledge unfolds unconsciously, whereas learning always involves conscious effort, and can only result in explicit knowledge gains. Since, in his view, internalizing linguistic knowledge takes place in two fundamentally different ways, resulting in two separate knowledge bases, Krashen stated that explicit knowledge could never be converted into implicit knowledge.

From such a non-interface viewpoint (e.g. Krashen, 1985; Schwartz, 1993), the line of reasoning behind the claim that CF does not play a facilitative role in the SLA process is thus as follows: while CF can only result in explicit knowledge, actual language use is totally driven by implicit knowledge. The idea that explicit knowledge will never become implicit, then renders the conclusion that learners' interlanguage system is unsusceptible to CF, or, in Truscott's (1996) words, that CF will only lead to "a superficial and possibly transient form of knowledge” (p. 345) or 'pseudolearning'.

Alternative perspectives are possible, however ${ }^{4}$. Many SLA researchers seem to converge on the position that there is an interface connecting implicit and explicit knowledge bases (e.g. DeKeyser, 1998; Hulstijn, 1995; Hulstijn \& Schmidt, 1994; McLaughlin, 1990; Schmidt, 1990; Schmidt \& Frota, 1986; Swain, 1985). Drawing on Skill Acquisition Theory 
(e.g. DeKeyser, 1998), they propose that the gap between explicit knowledge and language use can be gradually bridged by output practice (DeKeyser, 2003). By practicing language production, L2 learners are enabled to consolidate and automatize their linguistic repertoire (Manchón, in press). CF is believed to further assist this proceduralization of declarative L2 knowledge (Ellis, 2010).

Other scholars adhere to an intermediate position (e.g. Doughty \& Williams, 1998; Ellis, 1997; Long \& Robinson, 1998). They see implicit and explicit knowledge as being separated, but argue that explicit knowledge may feed into the intake process by helping learners notice the formal features of the input. From this perspective, CF could be expected to foster interlanguage development because it facilitates the process of noticing (the gap).

\subsection{Developmental Readiness}

Another theoretical objection raised by Truscott (1996) in his case against grammar correction relates to research into naturalistic SLA and the Natural Order Hypothesis (Krashen, 1981; 1982; 1985). Early studies (e.g. Bailey, Madden, \& Krashen, 1974; Dulay \& Burt, 1974; Pica, 1983) investigating the acquisition of learners in a naturalistic L2 environment, found that different grammatical features were acquired in a relatively strict, predefined order. These findings led Corder (1967) to suggest that learners will only be able to master linguistic forms in consonance with their own internal learning mechanisms, and not in the sequence imposed by a teacher or $\mathrm{L} 2$ syllabus.

A similar point was made in Pienemann's (1989) Teachability or Learnability hypothesis, which suggests that learners will only be able to acquire features for which they show developmental readiness. In Pienemann's view, features that are beyond a learners' stage of development will not be teachable because "the acquisition process cannot be steered or modeled just according to the requirements of formal instruction” (1989, p. 57). Truscott (1996) deduced that, to have any potential effect, teachers should align the CF they provide to a learner's current level of L2 development. If not, learners will be presented with grammatical structures that they are not yet ready to acquire, and as a result, no intake will take place. It has been pointed out, however, that the insights and research base concerning developmental sequences is still too limited to be useful for teaching practice (e.g. DeKeyser, 1998; Ellis, 1997; Truscott, 1996). This led Truscott (1996) to conclude that provision of aligned CF is not (yet) a feasible objective, and that error correction therefore cannot be expected to be beneficial to SLA. 


\subsection{Potential Harmful Side-Effects of CF}

CF opponents have not only stated that error correction is unable to lead to accuracy development, but some even argued that CF can be detrimental to the process of L2 acquisition.

A first reason for claiming that CF should be considered counterproductive, is that, in Truscott's (1996; 2004) view, the time and energy spent on dealing with corrections (both by teachers and students) could be allocated more efficiently to alternative activities, such as additional writing practice.

Secondly, both Krashen (e.g. 1982) and Truscott (e.g. 1996) suggested that, in making students aware of their errors, CF leads to learner stress and anxiety of committing the same errors in future writing. In their view, this anxiety could make learners avoid the erroneous constructions when writing a new text, resulting in simplified writing. This suggestion that the focus on language form induced by CF might lead to a reduction of the linguistic complexity of learners' output, is in line with predictions from limited capacity models of attention which also expect a trade-off between accuracy and complexity (e.g. Skehan, 1998). Within these models, L2 performance is expected to become more complex when learners are willing and feeling free to experiment with the target language. A focus on accuracy, on the other hand, "is seen to reflect a greater degree of conservatism" in which learners will try "to achieve greater control over more stable [interlanguage] elements” while avoiding extending their L2 repertoire (Skehan \& Foster, 2001, p. 191). From a multiple-resource perspective on attention (e.g. Robinson, 2003; 2005), however, linguistic accuracy and complexity are not presumed to be in competition because these two form-related aspects of learner output are thought to be closely connected.

\section{CONTROVERSIES CONCERNING THE USE OF CF IN L2 INSTRUCTION}

The previous sections discussed arguments both in favor and against the use of CF in L2 instruction. Even amongst CF advocates, however, some issues relating to the value of error correction remain divisive. In what follows, I will review two of the most heavily debated issues, which are (1) the differential effectiveness of various CF methodologies, and (2) the meanibility of different types of erros to CF.

\subsection{Which CF Method to Use}

CF on L2 learners' writing can take many different forms. Methodologies of written error correction may vary, for example, with respect to their explicitness, their focus, the person providing the feedback, the feedback medium, and so on. The two dichotomies which have 
been receiving the lion's share of researchers' attention are that between focused and unfocused CF, and the contrast between direct and indirect CF. The following is a synopsis of the different positions that have been advanced in the literature concerning the relative effectiveness of these different CF types.

\subsubsection{Focused and unfocused $C F$}

The focused-unfocused dichotomy refers to the comprehensiveness of correction methodologies. The unfocused (or comprehensive) approach involves correction of all errors in a learner's text, irrespective of their error category. Focused (or selective) CF, on the other hand, targets a (number of) specific linguistic feature(s) only (e.g. errors in the use of English articles). Errors outside the focus domain are left uncorrected.

Different predictions have been made with respect to the relative effectiveness of focused and unfocused CF. Ellis et al. (2008), for example, claimed that there are theoretical reasons for expecting the focused approach to be more beneficial to accuracy development than unfocused CF. They stated that learners are more likely to notice and understand corrections when they target a specific (set of) error type(s). The idea that noticing and understanding are essential for acquisition (e.g. Schmidt, 1994; Ellis, 2005), led Ellis et al. (2008) to conclude that focused CF has greater potential to impact accuracy development. Sheen (2007) and Bitchener (2008) furthermore argued that unfocused CF may not be the most effective correction method because L2 learners have a limited processing capacity. They claimed that asking learners to deal with CF which targets a broad range of linguistic features at the same time might produce a cognitive overload, and prohibit feedback processing. As noted earlier, however, this attentional capacity problem might be more prominent in the online processing of oral feedback than in the offline handling of written CF (e.g. Sheen, 2010a).

There are also reasons to question the hypothesized superiority of a focused CF approach. It could be argued that focused CF is rather a form of explicit grammar instruction than a focus-on-form intervention (e.g. Bruton, 2009). This might make it more difficult for learners to transfer what is learned from the feedback to new writing situations (e.g. Segalowitz, 1997; 2000). Furthermore, Ferris (2010) and Storch (this issue) noted that, from a practical perspective, only targeting specific error types might not be enough; a teacher's purpose in correcting his pupils' written work is (among other things) improving accuracy in general, not just the use of one grammatical feature. Moreover, observing that some of their errors have been corrected while others have not might be rather confusing for students.

\subsubsection{Direct and indirect $C F$}

The second much discussed contrast is that between direct and indirect error correction. The main factor distinguishing these two types of CF is the learner's involvement in the correction process. Whereas direct CF consists of an indication of the error and the corresponding 
correct linguistic form, indirect CF only indicates that an error has been made. Instead of the teacher providing the target form, it is left to the learner to correct his own errors. Indirect correction methods can take different forms that vary in their explicitness (e.g. underlining of errors, coding of errors).

Various hypotheses considering the relative effectiveness of direct and indirect CF have been put forward, some in favour of direct error correction, others supporting the indirect approach.

On the one hand, it has been suggested that learners will benefit more from indirect $\mathrm{CF}$ because they have to engage in a more profound form of language processing when they are self-editing their writing (e.g. Ferris, 1995; Lalande, 1982). In this view, the value of the indirect approach lies in the fact that it "requires pupils to engage in guided learning and problem solving and, as a result, promotes the type of reflection that is more likely to foster long-term acquisition” (Bitchener \& Knoch, 2008, p. 415).

Advocates of direct CF (e.g. Chandler, 2003), on the other hand, have claimed that the indirect approach might fail because indirect CF provides learners with insufficient information to resolve complex errors (e.g. syntactic errors). Chandler (2003) furthermore argued that, whereas direct CF enables learners to instantly internalize the correct form as provided by their teacher, learners whose errors are corrected indirectly do not know if their own hypothesized corrections are indeed accurate. This delay in access to the target form might level out the potential advantage of the additional cognitive effort associated with indirect CF. Additionally, Bitchener and Knoch (2010b) suggested that only direct CF offers learners the kind of explicit information that is needed for testing hypotheses about the target language.

It has also been suggested that the relative effectiveness of direct and indirect CF methodologies might be determined by intervening factors, such as a learner's level of L2 proficiency or meta-linguistic awareness (e.g. Ferris, 2004; Hyland \& Hyland, 2006), the type of error that is targeted (e.g. Ferris, 1999; 2002), the goal a teacher tries to achieve by providing CF (Ferris, 2010), or the type of knowledge (i.e. already partially acquired knowledge vs. new knowledge) a teacher opts to transfer (Ellis et al., 2008).

\subsection{Which Errors to Correct}

Apart from theorizing about the most effective CF methodology, researchers have also been concerned with the question which errors to target when providing CF. Various proposals have been advanced in relation to this issue.

Corder (1967), for example, differentiated between errors and mistakes. Errors, in his view, reveal gaps in learners' interlanguage system, and will therefore be systematic themselves. Unsystematic inaccuracies (i.e. slips of the tongue/pen), on the other hand, arise due to performance failures such as memory limitations. Corder suggested that it is useful to correct learners' errors but not their mistakes. 
Burt (1975; Burt and Kiparsky, 1972) distinguished between global and local errors. He labeled errors that could lead to communication breakdown by interfering with the comprehensibility of the utterance global errors (e.g. word order errors, lexical errors), whereas minor linguistic violations that do not affect the intended meaning of a message were categorized as local errors (e.g. morphological errors). Hendrickson (1978) recommended teachers to only correct global errors since they impair communication.

Although Krashen (1981; 1982; 1985) denied CF to have any role in L2 acquisition, he stated that CF could have value in enabling learners to monitor their L2 production. However, Krashen noted that this potentially facilitative effect of CF is limited to simple and portable features (e.g. third person - s in English), and that CF should therefore only target this type of errors.

Finally, Ferris (1999; 2002) made a distinction between treatable and untreatable errors. She labeled non-idiomatic or idiosyncratic errors as untreatable (e.g. lexical errors), and categorized errors in patterned and rule-governed features as treatable problems (e.g. article errors). Ferris suggested that CF would be most likely to be successful when directed at treatable inaccuracies.

In fact, problems exist with all of these proposals, and no clear theoretical basis has been provided for any of them. Ellis (2009) argued, for example, that the dichotomy between errors and mistakes is not as strict as Corder (1967) presented it to be, and stated that "the gravity of an error is to a very considerable extent a matter of personal opinion” (Ellis, 2009, p. 6). He furthermore noted that there are no theoretical grounds on which teachers or researchers can decide whether an error is simple and portable. The same holds for Ferris' dichotomy between treatable and untreatable errors.

In my opinion, the only operationalizable distinction is the contrast between grammatical errors and errors outside the grammatical domain, as proposed by Truscott (e.g. 1996; 2001; 2007). Like Krashen, Truscott predicted CF to have no potential value for the development of grammatical competence. He claimed that CF is unable to affect the rules underlying grammatical errors, and suggested that CF could only be beneficial for errors that "are relatively simple and can be treated as discrete items rather than integral parts of a complex system” (Truscott, 2007, p. 258), such as spelling errors. Interestingly, in applying this discreteness criterion, Truscott's predictions concerning the amenability of some types of errors are contradicting those of Ferris (1999, 2002). Whereas Truscott (2001) claimed that lexical errors, for example, belong to the most correctible L2 problems because they are relatively discrete, Ferris suggested that it is precisely the idiosyncrasy of lexical errors which makes them less suitable targets for CF. 


\section{SYNTHESIS AND CRITICAL REVIEW OF EMPIRICAL CF WORK}

Because the role of written CF in L2 acquisition is still a controversial one, the topic has been and still is attracting a lot of research attention. The present review focuses on the body of empirical studies that opted to add to the writing-to-learn agenda by investigating if CF facilitates learners' written accuracy development ${ }^{5}$. This section will consecutively discuss insights concerning (1) the potential of CF in yielding accuracy improvement, (2) the differential effectiveness of direct and indirect correction methodologies, (3) the amenability of different error types to CF, and (4) the possible negative side-effects of error correction.

\subsection{Research on the Effectiveness of Written CF}

\subsubsection{Early research}

The earlier work on the effect of CF on L2 learners' written accuracy could be categorized into two strands. While the first set of studies focused on the role of CF during the revision process (e.g. Ashwell, 2000; Fathman \& Whalley, 1990; Ferris, 1997; Ferris \& Roberts, 2001), the second group of investigations set out to answer the question if correction yields a learning effect (e.g. Chandler, 2003; Kepner, 1991; Polio et al., 1998; Semke, 1984; Sheppard, 1992).

The revision studies revealed that CF enables L2 students to improve the accuracy of a particular piece of writing during revision (e.g. Ashwell, 2000; Fathman \& Whalley, 1990; Ferris, 1997; Ferris \& Roberts, 2001). This finding is valuable from a learning-to-write perspective because it shows that $\mathrm{CF}$ has the ability to help learners develop more effective revision and self-editing skills (Ferris, 2010). From a SLA viewpoint, however, such revision studies are less compelling. Polio et al. (1998) already identified development (i.e. the longterm effects of pedagogical interventions such as CF) to be the ultimate concern of SLA research. Truscott and Hsu (2008) were therefore right in claiming that, in only comparing two versions of the same text, the revision studies do not provide evidence of L2 acquisition. Instead, evaluating the potential of CF in yielding a learning effect would necessarily involve “a comparison between two independently written works” (Truscott \& Hsu, 2008, p. 293).

Studies that could shed light on the role of error correction in accuracy development are the ones that investigate the effect of CF on new pieces of writing. Earlier studies that did opt to provide insights into the SLA potential of CF, however, rendered inconclusive results (e.g. Chandler, 2003; Kepner, 1991; Polio et al., 1998; Semke, 1984; Sheppard, 1992). Since their conflicting findings could be attributed to methodological issues (such as time-on-task differences or the lack of a control group ${ }^{6}$ ), both opponents (e.g. Truscott, 1996) and advocates (e.g. Ferris, 1999) of written CF called for more, well designed CF studies. 


\subsubsection{Recent research}

The above mentioned appeal has resulted in a growing body of tightly controlled investigations, exploring the long-term effects of CF on L2 writing, by comparing learners' accuracy performance on pre-tests and (delayed) post-tests. When considering the type of feedback under investigation, these studies fall into three groups: those evaluating the effectiveness of focused CF, those examining the effects of comprehensive or unfocused correction, and those comparing the efficacy of focused and unfocused CF approaches.

\subsection{2.a. Research on the effectiveness of focused CF}

Most recent CF research explored the effects of focused CF (e.g. Bitchener, 2008; Bitchener \& Knoch, 2008; Bitchener \& Knoch, 2009; Bitchener \& Knoch, 2010a; Bitchener \& Knoch, 2010b; Ellis et al., 2008; Sheen, 2007; Sheen, 2010b). Following the methodology of oral feedback studies (e.g. Lyster, 2004; Ellis, Loewen, \& Erlam, 2006), the focused CF approach targets specific, persistently problematic features only (e.g. errors in the use of English articles), leaving errors outside the focus domain uncorrected. These tightly controlled studies all found robust positive effects of focused $\mathrm{CF}^{7}$. Moreover, the reported accuracy gains proved to be very durable; Bitchener and Knoch (2010a), for example, showed that students who had received focused CF (only once) continued to outperform students whose errors had not been corrected over a 10-month period.

\subsection{2.b. Research on the effectiveness of unfocused CF}

As compared to the growing amount of evidence on the effectiveness of focused CF, proof on the benefits of comprehensive or unfocused CF is still scarce. Only three recent studies that I am aware of, aimed at investigating its potential to aid SLA (Truscott \& Hsu, 2008; Van Beuningen, De Jong, \& Kuiken, 2008; Van Beuningen, De Jong \& Kuiken, accepted for publication).

The first one (Truscott \& Hsu, 2008) contrasted a group receiving unfocused CF to a control group whose errors were not corrected. Truscott and Hsu found that, while comprehensive $\mathrm{CF}$ enabled their learners to improve the accuracy of a particular text during revision, it did not lead to accuracy gains in a new text. However, the fact that unfocused CF did not lead to learning in this study might have been attributable to a ceiling effect (Bruton, 2009); the texts learners wrote during the pre-test held very few errors to begin with, and, as a result, little room was left for CF invoked improvement in the post-test.

The two other studies do seem to indicate that comprehensive error correction is beneficial to the SLA process (Van Beuningen et al., 2008; Van Beuningen et al., accepted for publication $)^{8}$. Both were tightly controlled classroom-based studies exploring the effects of two types of unfocused CF and two control treatments on learners' accuracy development. They found that comprehensive error correction not only led to improved accuracy in the revised version of a particular piece of writing, but that it also yielded a learning effect; 
learners who received unfocused CF made significantly fewer errors in newly produced texts (i.e. written one and four weeks after CF provision) than pupils whose errors had not been corrected.

\subsection{2.c. Research on the relative effectiveness of focused and unfocused CF}

Little is known about the relative effectiveness of focused and unfocused CF. The only two studies addressing this issue are Ellis et al. (2008) and Sheen, Wright, and Moldawa (2009).

Ellis et al. (2008) did not find any differences in accuracy gains between their focused and unfocused CF groups. However, this study had various methodological weaknesses (see $\mathrm{Xu}, 2009$ for a discussion). One of the problems the authors themselves mentioned, is that students in the focused group received more feedback on the target feature (i.e. articles) than students in the unfocused group.

Sheen et al. (2009) found the focused approach to be more beneficial than provision of comprehensive feedback. However, as acknowledged by the authors themselves, the CF received by the unfocused group was rather unsystematic in nature; while some errors were corrected, others were ignored. It is conceivable that this unsystematic way of correcting has negatively influenced the effect of unfocused CF in this study; students might have been confused noticing that some of their errors had been disregarded ${ }^{9}$.

\subsection{Research on the Differential Effectiveness of Direct and Indirect CF Methodologies}

As already explained, different CF methodologies have often been categorized as either direct or indirect types of correction, and various hypotheses concerning their relative effectiveness have been put forward. A reasonable number of studies opted to gain insights into the differential effects of direct and indirect CF on learners' written accuracy development.

Early research on the issue produced conflicting results (e.g. Chandler, 2003; Ferris, 2006; Frantzen, 1995; Lalande, 1982; Rob, Ross, \& Shortreed, 1986). The main causes of this lack of convergence could be found in design-related and analytical problems (for a full review of these methodological issues see Van Beuningen et al., accepted for publication). Lalande (1982), for example, reported an advantage of indirect over direct CF. However, the observed between-group accuracy difference was not statistically significant. In contrast to Lalande, Chandler (2003) claimed direct correction to be the most effective CF approach, but the difference she reported also failed to reach significance. Moreover, studies by Frantzen (1995) and Robb, Ross, and Shortreed (1986) did not find any clear differences in accuracy improvement between groups receiving direct CF and groups whose errors were corrected indirectly.

More recently, Van Beuningen et al. (2008) cautiously suggested that direct CF might be more beneficial than indirect correction. This conclusion was based on the observation that learners receiving direct CF significantly outperformed pupils in two control groups when 
writing a new text, whereas the indirect CF group (whose errors were coded) did not. However, the difference between the two feedback groups only took the form of a trend at a p-value of .06. Bitchener and Knoch (2010b) also reported an advantage of direct correction. Whereas in this study direct and indirect CF proved to be equally effective in improving learners' accurate use of English articles over a one week period, only the effect of the two direct CF treatments was still present ten weeks later. Finally, as will be explained in the following section, findings from a follow-up to their 2008 study led Van Beuningen et al. (accepted for publication) to suggest that the relative effectiveness of direct and indirect correction is dependent on the type of error that is targeted.

\subsection{Research on the Value of CF for Different Error Types}

It has been argued that one could not expect all linguistic errors to be equally amenable to (the same type of) CF (e.g. Ferris, 1999; Truscott, 1996), because morphological, syntactic, and lexical errors represent gaps within different domains of linguistic knowledge (e.g. Schwartz, 1993). Although various hypotheses regarding the CF responsiveness of different types of errors have been forwarded over the years, the question which errors to correct remains an empirical one.

A number of studies explored the effects of CF on separate error types, and all reported differing levels of improvement for different types of errors (e.g. Bitchener, Young, \& Cameron, 2005; Ferris, 2006; Ferris \& Roberts, 2001; Frantzen, 1995; Lalande, 1982; Sheppard, 1992). Ferris (2006), for example, differentiated between five major error categories (i.e. verb errors, noun errors, article errors, lexical errors, and sentence errors), and found that students receiving CF only realized a significant reduction from pre-test to posttest in verb errors. Furthermore, Lalande (1982) discerned 12 error types, and observed that correction only led to a significant decrease in orthographical errors. Bitchener et al. (2005) investigated how CF influenced learners' accuracy development on three target structures, and found that CF had a greater effect on the accuracy of past simple tense and articles than on the correct usage of prepositions.

Rather than exploring the effect of CF on separate types of errors, Van Beuningen et al. (accepted for publication) investigated the correctability of grammatical (i.e. syntactic errors) and non-grammatical problems (i.e. spelling errors). In doing so, they aimed at testing Truscott's (1996; 2001; 2007) claim that, if CF has any value, this could only be true for nongrammatical errors, and not for errors in grammar. Results showed that both learners' grammatical and non-grammatical problems are amenable to CF. This study furthermore revealed an interaction between error type and CF methodology: whereas direct CF proved to be most effective in remedying grammatical errors (e.g. morphological errors, syntactic errors), learners' improvement on non-grammatical features (e.g. spelling errors, punctuation errors) was retained the longest when indirect corrections were provided. 


\subsection{Research on the Potential Harmful Side-Effects of CF}

As was explained in the theoretical section of the present paper, one of the reasons for CF opponents (e.g. Truscott, 1996) to object against the use of CF in L2 (writing) classes, is that it may lead to simplified writing by triggering learners to avoid situations in which they make errors. These considerations led Truscott $(2004 ; 2007)$ to propose that accuracy gains found in earlier correction studies (e.g. Chandler, 2003) might well have been attributable to such avoidance and simplified writing instead of to CF.

Few studies have investigated the influence of written CF on linguistic complexity. Of the studies that did (e.g. Chandler, 2003; Robb et al., 1986; Sheppard, 1992; Van Beuningen et al., accepted for publication), the majority could not come to any warranted conclusions because of inadequate methodology and analysis ${ }^{10}$. Sheppard (1992) reported a negative effect of CF on the structural complexity of learners' writing, but in fact his finding was nonsignificant. Robb et al. (1986) found CF to have a significant positive effect on written complexity, but this study did not include a control group who did not receive CF. The same holds for Chandler's (2003) study, which concluded that CF did not affect the complexity of students' writing as measured by holistic ratings.

Van Beuningen et al. (accepted for publication) tried to overcome the shortcomings of earlier studies. They investigated the effect of error correction on both the lexical and structural complexity of learners' writing. This study showed that the writing produced by pupils who received CF was not lexically or structurally less complex than that of pupils in two control groups.

A second argument that led Truscott $(1996 ; 2004)$ to conclude that CF should be expected to harm L2 learners' accuracy development, is that it diverts time and energy away from more productive aspects of writing instruction. Three studies directly tested this claim by comparing the effects of CF to those of writing practice (Sheen et al., 2009; Van Beuningen et al., 2008; Van Beuningen et al., accepted for publication). They all oppose Truscott's hypothesis by showing that correction was more beneficial to learners' accuracy development than mere writing practice.

\section{DISCUSSION}

The aim of the present paper was to review some of the theoretical perspectives, as well as the available empirical evidence on the role of written CF in SLA. In spite of the disagreements on the L2 learning potential of CF in L2 (writing) classrooms, there now seems to be growing evidence that error correction is an effective means of improving L2 learners' written accuracy over time. A body of recent, tightly controlled CF studies was able to show that learners still benefit from the CF they received on earlier writing when producing new texts. 
Importantly, this CF invoked accuracy improvement proved to be durable; some of the studies still observed positive effects of written error correction as long as ten months after the CF had been provided. Bitchener and Knoch (2010a) were therefore right in stating that - even though it remains an empirical question whether the knowledge inferred from correction is implicit or explicit in nature - these findings do counter the claim that CF can only lead to 'pseudolearning' (e.g. Truscott, 1996). Moreover, Truscott's (1996) hypothesis that CF might come with negative side-effects harming learners' L2 development was also refuted by findings from a small number of studies; CF did not seem to affect the complexity of learners' writing, and correction proved to lead to greater accuracy gains than mere writing practice (e.g. Van Beuningen et al., accepted for publication).

Apart from the overall value of written error correction to L2 development, SLA theorists and researchers have been concerned with more specific issues, such as the relative effectiveness of various CF methodologies and the correctability of different error types. A related first conclusion that arises from the available empirical data, is that learners can benefit from both focused (i.e. CF targeting a specific type of errors only) and unfocused CF (i.e. CF targeting all errors, irrespective of the error type). One of the theoretical implications of this finding is that learners seem to have enough attentional resources available to be able to attend to a broad range of linguistic features within one text. As already suggested, it might be the offline character of writing that prevents learners from becoming cognitively overloaded when presented with unfocused or comprehensive corrections (e.g. Sheen, 2010a). A second observation is that no error type has proven to be uncorrectable, and that Truscott's (2001; 2007) hypothesis that grammatical errors are insusceptible to CF could thus be rejected. Finally, empirical evidence so far seems to suggest that learners benefit more from direct correction than from indirect CF, especially when CF targets errors within the grammatical domain. One possible explanation might be that only direct CF presents learners with the kind of explicit information that is needed for cognitive learning processes, such as noticing and hypothesis testing (e.g. Bitchener \& Knoch, 2010b).

\subsection{Directions for Future Research}

Even though the insights from recent SLA oriented CF research greatly contribute to the error correction debate by tackling the question if CF has the ability to lead to written accuracy development, there are still many issues that are in need of further exploration. This section will present some suggestions and directions for future CF research.

To begin with, I would like to argue that the learning potential of comprehensive or unfocused CF deserves more attention. Whereas a few studies recently provided evidence on the effectiveness of comprehensive correction, the focus of current CF studies has mainly been on establishing the value of selective or focused CF. There are several reasons, however, to consider further investigation of the effects of unfocused CF important (see also Storch, 
this issue). Firstly, comprehensive CF seems to be the most authentic feedback methodology. As noted by several researchers (i.e. Ferris, 2010; Hartshorn et al., 2010), teachers who provide CF usually opt to improve the overall accuracy of their students' writing, not just the use of one specific linguistic feature. Moreover, Bruton (2009) questioned the extent to which the focused CF studies can still be considered to concern genuine L2 writing. In focusing on just one language feature their materials and CF rather seem to constitute written grammar exercises than authentic writing tasks. Xu (2009) addressed a similar point by stating that a clear focus on one grammatical structure may lead learners to consciously monitor the use of that target feature when performing the post-test(s). Finally, both Truscott (2010) and Ferris (2010) argued that the implications which can be drawn from focused CF studies so far are quite narrow, since they all targeted relatively simple linguistic problems (i.e. article errors).

A second issue that future studies should attend to is the CF responsiveness of different types of errors. Even though research was already able to show that both grammatical errors and errors outside the grammatical domain benefit from correction, it could be expected that within these two broad domains separate error types still differ in their level of CF amenability (e.g. Ferris, 1999; Truscott, 2001). Earlier studies that compared the effects of CF across separate error categories, however, have been too heterogeneous (with respect to the types of errors targeted, CF type, research design and context, etc.) to result in any definitive conclusions.

Thirdly, I support Storch's (this issue) call for more qualitative CF studies. The majority of CF research to date investigated the effectiveness of error correction by looking at group performances on global accuracy measures (i.e. number of errors per 100 words, number of error-free T-units, etc.) over time. For various reasons, however, it could be considered useful to (also) take a more detailed look at individual learners' sequential accuracy performance. Storch and Wigglesworth (2010), for example, argued that analyzing how learners actually use CF could provide insights on how and when learners benefit from error correction. Moreover, Bruton (2009) suggested that detailed, qualitative analysis of learners' writing performance over time might give a more complete and accurate picture of the accuracy gains brought about by CF than the more common global measures.

Fourthly, it is important that studies investigating the effect of CF on L2 learners' accuracy development also explore whether and how correction impacts the complexity of students' writing. Without incorporating measures of lexical and structural complexity, the possibility that any CF invoked accuracy improvement is actually brought about by avoidance of more complex language use could not be ruled out (Truscott, 1996).

Finally, feedback needs to be provided within a realistic writing context to enable valid assessment of the role of CF in L2 learners' written accuracy development. Long (2007), for example, claimed that development can only be measured by examining language use during unmonitored production, when learners' focus is on content rather than on 
language as an object. The tasks used in earlier CF studies, however, have often (but not always) been very artificial with a clear focus on linguistic accuracy.

\subsection{Conclusion}

Whereas the value of written CF for L2 acquisition has been heavily contested (e.g. Truscott, 1996; 1999; 2007), recent studies have provided robust evidence on the efficacy of error correction. The fact that the accuracy improvement brought about by written CF was shown to be durable, rebuts Truscott's (1996) claim that correction can only lead to a superficial and transient type of L2 knowledge. I conclude that, by offering learners opportunities to notice the gaps in their developing L2 systems, test interlanguage hypotheses, and engage in metalinguistic reflection, written CF has the ability to foster SLA and to lead to accuracy development.

\section{NOTES}

${ }^{1}$ Although in psycholinguistic and cognitive SLA accounts the general consensus is that attention is a necessary condition for language learning (e.g. Robinson, 2003; Schmidt, 1990; 1994; 2001; Sharwood Smith, 1993; VanPatten \& Cadierno, 1993), there is disagreement on the level of awareness that should be involved (e.g. Robinson, 2003; Schmidt, 2001; Tomlin \& Villa, 1994). See for example Schmidt (2001) for an elaborate account of attention related issues in SLA.

${ }^{2}$ It needs to be noted that not all types of output are expected to serve these functions (e.g. Ellis, 2005). The complexity and length of output resulting from controlled practice exercises for example, is too limited to be beneficial to interlanguage development.

${ }^{3}$ This assumption holds for oral L2 use in particular. As Bitchener \& Knoch (2010a) stated, "the extent to which learners draw upon explicit and implicit knowledge during the writing process is not known. It is likely, however, that they draw upon both explicit and implicit linguistic knowledge” (p. 4). This point will be further addressed in the discussion section of the present paper.

${ }^{4}$ See e.g. DeKeyser (2003) for a comprehensive account of opposing views on the relation between implicit and explicit L2 knowledge.

${ }^{5}$ Although the writing-to-learn agenda also involves research on the question how CF contributes to SLA processes such as noticing (e.g. Santos et al., 2010; Storch \& Wigglesworth, 2010; Swain \& Lapkin, 2002; Qi \& Lapkin, 2001), this paper will only focus on studies investigating the outcome of the learning process (i.e. accuracy development).

${ }^{6}$ See Ferris (2004), Guenette (2007), and Storch (this issue) for reviews of these design related problems.

${ }^{7}$ See Xu (2009), however, for a critical discussion of the findings by Bitchener (2008) and Ellis et al. (2008), and see Bitchener (2009) for a response. See also Storch (this issue) for an apprehensive review of recent CF studies. 
${ }^{8}$ See Storch (this issue), however, for some critical remarks concerning the study by Van Beuningen et al. (2008).

${ }^{9}$ Sheen et al. (2009) justified the unsystematic nature of the unfocused CF treatment in their study by arguing that, in reality, teachers also tend to provide comprehensive feedback in an unsystematic and confusing manner. Even if this is the case, however, it would not validate doing the same for research purposes. What Sheen et al. have been comparing is not focused and unfocused CF per se, but focused $\mathrm{CF}$ and an inferior form of unfocused CF. The fact that the focused approach proved to be more beneficial than comprehensive correction in this study, does not warrant the conclusion that unfocused $\mathrm{CF}$ is necessarily less effective. It only shows that high quality focused feedback is more useful than badly provided unfocused CF.

${ }^{10}$ See Van Beuningen et al. (accepted for publication) for a full review of these design-related issues.

\section{REFERENCES}

Adams, R. (2003). L2 output, reformulation and noticing: implications for IL development. Language Teaching Research 7(3), 347-376.

Al-Hejin, B. (2004). Attention and awareness: Evidence from cognitive and second language research. Teachers College, Columbia University Working Papers in TESOL \& Applied Linguistics 4(1), $1-22$.

Ashwell, T. (2000). Patterns of teacher response to student writing in a multiple-draft composition classroom: Is content feedback followed by form feedback the best method? Journal of Second Language Writing 9(3), 227-258.

Bailey, K., Madden, C., \& Krashen, S. (1974). Is there a "natural sequence" in adult second language learning. Language Learning 24(2), 235-243.

Bialystok, E. (1994). Analysis and control in the development of second language proficiency. Studies in Second Language Acquisition 16(2), 157-168.

Bitchener, J., (2008). Evidence in support of written corrective feedback. Journal of Second Language Writing 17(2), 102-118.

Bitchener, J. (2009). Measuring the effectiveness of written corrective feedback: A response to "Overgeneralization from a narrow focus: A response to Bitchener (2008)". Journal of Second Language Writing, 18(4), 276-279.

Bitchener, J., \& Knoch, U. (2008). The value of written corrective feedback for migrant and international students. Language Teaching Research Journal 12(3), 409-431.

Bitchener, J., \& Knoch, U. (2009). The value of a focused approach to written corrective feedback. ELT Journal 63(3), 204-211.

Bitchener, J., \& Knoch, U. (2010a). The contribution of written corrective feedback to language development: a ten month investigation. Applied Linguistics 31(2), 193-214.

Bitchener, J., \& Knoch, U. (2010b). Raising the linguistic accuracy level of advanced L2 writers with written corrective feedback. Journal of Second Language Writing 19(4), 207-217.

Bitchener, J., Young, S., \& Cameron, D. (2005). The effect of different types of corrective feedback on ESL student writing. Journal of Second Language Writing 14(3), 227-258.

Bruton, A. (2009). Designing research into the effect of error correction in L2 writing: not so straightforward. Journal of Second Language Writing 18(2), 136-140.

Burt, M. (1975). Error analysis in the adult ESL classroom. TESOL Quarterly 9(1), 53-63.

Burt, M., \& Kiparsky, C. (1972). The gooficon: A repair manual for English. Rowley, MA: Newbury House.

Canale, M., \& Swain, M. (1980). Theoretical bases of communicative approaches to second language teaching and testing. Applied Linguistics 1(1), 1-47. 
Chandler, J. (2003). The efficacy of various kinds of error feedback for improvement in the accuracy and fluency of L2 student writing. Journal of Second Language Writing 12(3), 267-296.

Corder, P. (1967). The significance of learner errors. International Review of Applied Linguistics 5(4), 161-169.

DeKeyser, R.M. (1994). Implicit and explicit learning of second language grammar: A pilot study. TESOL Quarterly 28(1), 188-194.

DeKeyser, R. M. (1998). Beyond focus on form: Cognitive perspectives on learning and practicing second language grammar. In C. Doughty \& J. Williams (Eds.), Focus on form in classroom second language acquisition (pp. 42-63). Cambridge: Cambridge University Press.

DeKeyser, R. M. (2003). Implicit and explicit learning. In C. J. Doughty \& M. H. Long (Eds.), Handbook of second language acquisition (pp. 313-348). Oxford: Blackwell.

Doughty, C. J. (2003). Instructed SLA: Constraints, compensation, and enhancement. In C. J. Doughty \& M. H. Long (Eds.), Handbook of second language acquisition (pp. 256-310). Oxford: Blackwell.

Doughty, C., \& Williams, J. (1998). Pedagogical choices in focus on form. In C. J.Doughty \& J. Williams (Eds.), Focus on form in classroom second language acquisition (pp. 197-261). Cambridge: Cambridge University Press.

Dulay, H. S., \& Burt, M. K. (1974). Natural sequences in child second language acquisition. Language Learning 24(1), 37-53.

Ellis, R. (1995). Interpretation tasks for grammar teaching. TESOL Quarterly 29(1), 87-106.

Ellis, R. (1997). SLA research and language teaching. Oxford: Oxford University Press.

Ellis, R. (2003). Task-based language learning and teaching. Oxford: Oxford University Press.

Ellis, R. (2004). The definition and measurement of L2 explicit knowledge. Language Learning 54(2), 227-275.

Ellis, R. (2005). Principles of instructed language learning. System 33(2), 209-224.

Ellis, R. (2009). Corrective feedback and teacher development. L2 Journal 1(1), 3-18.

Ellis, R. (2010). A framework for investigating oral and written corrective feedback. Studies in Second Language Acquisition 32(2), 335-349.

Ellis, R., Basturkmen, H., \& Loewen, S., (2002). Doing focus-on-form. System 30(4), 419-432.

Ellis, R., Loewen, S., \& Erlam, R. (2006). Implicit and explicit corrective feedback and the acquisition of L2 grammar. Studies in Second Language Acquisition 28(2), 339- 368.

Ellis, R., Sheen, Y., Murakami, M., \& Takashima, H., (2008). The effects of focused and unfocused written corrective feedback in an English as a foreign language context. System 36(3), 353-371.

Fathman, A., \& Whalley, E. (1990). Teacher response to student writing: Focus on form versus content. In B. Kroll (Ed.), Second Language Writing: Research Insights for the Classroom (pp. 178-190). Cambridge: Cambridge University Press.

Ferris, D. (1995). Teaching ESL composition students to become independent self- editors. TESOL Journal 4(4), 18-22.

Ferris, D. (1997). The influence of teacher commentary on student revision. TESOL Quarterly 31(2), 315-339.

Ferris, D. (1999). The case of grammar correction in L2 writing classes: a response to Truscott (1996). Journal of Second Language Writing 8(1), 1-11.

Ferris, D. (2002). Treatment of error in second language student writing. Michigan: The University of Michigan Press.

Ferris, D. (2004). The "grammar correction" debate in L2 writing: Where are we, and where do we go from here? (and what do we do in the meantime?). Journal of Second Language Writing 13(1), 49-62.

Ferris, D. (2006). Does error feedback help student writers? New evidence on the short- and long-term effects of written error correction. In K. Hyland \& F. Hyland (Eds.), Feedback in second language writing: Contexts and issues (pp.81-104). Cambridge: Cambridge University Press.

Ferris, D. (2010). Second language writing research and written corrective feedback in SLA. Studies in Second Language Acquisition 32(2), 181-201.

Ferris, D., \& Roberts, B. (2001). Error feedback in L2 writing classes. How explicit does it need to be? Journal of Second Language Writing 10(3), 161-184. 
Frantzen, D. (1995). The effects of grammar supplementation on written accuracy in an intermediate Spanish content course. The Modern Language Journal 79(3), 329-344.

Gass, S. M. (1997). Input, interaction and the development of second languages. Mahwah, NJ: Lawrence Erlbaum Associates.

Guénette, D. (2007). Is feedback pedagogically correct? Research design issues in studies of feedback on writing. Journal of Second Language Writing 16(1), 40-53.

Han, Z-H. (2002). Rethinking the role of corrective feedback in communicative language teaching. RELC Journal 33(1), 1-34.

Harklau, L. (2002). The role of writing in classroom second language acquisition. Journal of Second Language Writing 11(4), 329-350.

Hartshorn, K. J., Evans, N. W., Merrill, P. F., Sudweeks, R. R., Strong-Krause, D., \& Anderson, N. J. (2010). Effects of dynamic corrective feedback on ESL writing accuracy. TESOL Quarterly 44(1), 84-109.

Hendrickson, J. M. (1978). Error correction in foreign language teaching: Recent theory, research and practice. Modern Language Journal 62(8), 387-398.

Hulstijn, J. H. (1995). Not all grammar rules are equal: giving grammar instruction its proper place in foreign language teaching. In R. Schmidt (Ed.), Attention and awareness in foreign language learning (pp. 359-386). Honolulu: University of Hawaii.

Hulstijn, J. H. \& Schmidt, R. (1994). Guest editors' introduction (to special issue on consciousness in second language learning. AILA Review 11, 5-10.

Hyland, K., \& Hyland, F. (2006). Feedback on second language students' writing. Language Teaching 39(2), 83-101.

Hymes, D. (1971). On communicative competence. Philadelphia: University of Pennsylvania Press.

Kepner, C. (1991). An experiment in the relationship of types of written feedback to the development of second language writing skills. The Modern Language Journal 75(3), 305-313.

Krashen, S. (1981). Second language acquisition and second language learning. Oxford: Pergamon Press.

Krashen, S. (1982). Principles and practice in second language acquisition. Oxford: Pergamon Press.

Krashen, S. (1985). The input hypothesis: Issues and implications. London: Longman.

Krashen, S. (1989). We acquire vocabulary and spelling by reading: Additional evidence for the input hypothesis. Modern Language Journal 73(4), 440-464.

Krashen, S., \& Terrell, T. (1983). The natural approach: Language acquisition in the classroom. Oxford: Pergamon Press.

Lalande, J. F. (1982). Reducing composition errors: An experiment. The Modern Language Journal 66(2), 140-149.

Leki, I., Cumming, A., \& Silva, T. (2008). A synthesis of research on second language writing in English. London: Routledge.

Li, S. (2010). The effectiveness of corrective feedback in SLA: A meta-analysis. Language Learning 60(2), 309-365.

Long, M. H. (1985). Input and second language acquisition theory. In S. M. Gass, \& C. G. Madden (Eds.), Input in second language acquisition (pp. 377-393). Rowley, MA: Newbury House.

Long, M. H. (1991). Focus on form: A design feature in language teaching methodology. In K. de Bot, D. Coste, R. Ginsberg, \& C. Kramsch (Eds.), Foreign language research in cross-cultural perspectives (pp. 39-52). Amsterdam/Philadelphia: John Benjamins Publishing Company.

Long, M. H. (1996). The role of linguistic environment in second language acquisition. In W. C. Ritchie \& B. K. Bahtia (Eds.), Handbook of second language acquisition (pp. 413-468). New York: Academic Press.

Long, M. H. (2000). Focus on form in task-based language teaching. In R. Lambert \& E. Shohamy (Eds.), Language policy and pedagogy. Essays in honor of A. Ronald Walton (pp. 179-192). Amsterdam/Philadelphia: John Benjamins Publishing Company.

Long, M. H. (2007). Problems in SLA. Mahwah, NJ: Lawrence Erlbaum Associates.

Long, M. H., \& Robinson, P. (1998). Focus on form: Theory, research, and practice. In C. Doughty \& J. Williams (Eds.), Focus on form in second language acquisition (pp.15-41). Cambridge: Cambridge University Press. 
Lyster, R. 2007. Learning and teaching languages through content: a counterbalanced approach. Amsterdam/Philadelphia: John Benjamins Publishing Company.

Lyster, R. (2004). Different effects of prompts and recasts in form-focused instruction. Studies in Second Language Acquisition 26(3), 399-432.

Lyster, R., \& Saito, K. (2010). Oral feedback in classroom SLA: A meta-analysis. Studies in Second Language Acquisition 32(2), 265-302.

Mackey, A., \& Goo, J. (2007). Interaction research in SLA: A meta-analysis and research synthesis. In A. Mackey (Ed.), Conversational interaction in second language acquisition: A series of empirical studies (pp. 407-452). Oxford: Oxford University Press.

Manchón, R. M. (2009). Broadening the perspective of L2 writing scholarship: The contribution of research on foreign language writing. In R. M. Manchón (Ed.), Writing in foreign language contexts. Learning, teaching, and research (pp. 1-19). Clevedon: Multilingual Matters.

Manchón, R. M. (in press). The language learning potential of writing in foreign language contexts. Lessons from research. In M. Reichelt \& T. Cimasko (Eds.), Foreign language writing. Research insights. West Lafayette: Parlor Press.

McLaughlin, B. (1990). “Conscious” versus “unconscious” learning. TESOL Quarterly 24(4), 617634.

Norris, J., \& Ortega, L. (2000). Effectiveness of L2 instruction: A research synthesis and quantitative meta-analysis. Language Learning 50(3), 417-528.

Ortega, L. (2009). Studying writing across EFL contexts: Looking back and moving forward. In R. M. Manchón (Ed.), Writing in foreign language contexts. Learning, teaching, and research (pp. 232-255). Clevedon: Multilingual Matters.

Pica, T. (1983). Adult acquisition of English as a second language under different conditions of exposure. Language Learning 33(4), 465-497.

Pienemann, M. (1989). Is language teachable? Applied Linguistics 10(1), 52-79.

Pienemann, M. (1998). Language processing and second language development: Processability theory. Amsterdam/Philadelphia: John Benjamins Publishing Company.

Polio, C., Fleck, C., \& Leder, N. (1998). "If only I had more time": ESL learners' changes in linguistic accuracy on essay revisions. Journal of Second Language Writing 7(1), 43-68.

Qi, D. S., \& Lapkin, S. (2001). Exploring the role of noticing in a three-stage second language writing task. Journal of Second Language Writing 10(4), 277-303.

Révész, A. J. (2007). Focus on form in task-based language teaching: Recasts, task complexity, and L2 learning. Unpublished doctoral dissertation, Columbia University.

Robb, T., Ross, S., \& Shortreed, I. (1986). Salience of feedback on error and its effect on EFL writing quality. TESOL Quarterly 20(1), 83-95.

Robinson, P. (2003). Attention and memory during SLA. In C. J. Doughty \& M. H. Long (Eds.), Handbook of second language acquisition (pp. 631-678). Oxford: Blackwell.

Robinson, P. (2005). Cognitive complexity and task sequencing: studies in a componential framework for second language task design. International Review of Applied Linguistics 43(1), 1-32.

Santos, M., López-Serrano, S., \& Manchón, R. M. (2010). The differential effect of two types of direct written corrective feedback on noticing and uptake: Reformulation vs. error correction. International Journal of English Studies 10(1), 131-154.

Schmidt, R. (1990). The role of consciousness in second language learning. Applied Linguistics 11(2), 129-158.

Schmidt, R. (1994). Deconstructing consciousness in search of useful definitions for applied linguistics. AILA Review 11, 11-26.

Schmidt, R. (2001). Attention. In P. Robinson (Ed.), Cognition and second language instruction (pp. 3-32). Cambridge: Cambridge University Press.

Schmidt, R., \& Frota, S. (1986). Developing basic conversational ability in a foreign language: A case study of an adult learner of Portuguese. In R. Day (Ed.), Talking to Learn (pp. 237-326). Rowley, MA: Newbury House.

Schwartz, B. D. (1993). On explicit and negative data effecting and affecting competence and linguistic behavior. Studies in Second Language Acquisition 15(2), 147-163. 
Segalowitz, N. (1997). Individual differences in second language acquisition. In A. M. B. De Groot \& J. F. Kroll (Eds.), Tutorials in bilingualism: Psycholinguistic perspectives (pp. 85-112). Mahwah, NJ: Lawrence Erlbaum Associates.

Segalowitz, N. (2000). Automaticity and attentional skill in fluent performance. In H. Riggenbach (Ed.), Perspectives on fluency (pp. 200-219). Ann Arbor, MI: University of Michigan Press.

Semke, H. (1984). The effects of the red pen. Foreign Language Annuals 17(3), 195-202.

Sharwood Smith, M. (1993). Input enhancement in instructed SLA: Theoretical bases Studies in Second Language Acquisition 15(2), 165-179.

Sheen, Y. (2007). The effect of focused written corrective feedback and language aptitude on ESL learners’ acquisition of articles. TESOL Quarterly 41(2), 255-283.

Sheen, Y. (2010a). The role of oral and written corrective feedback in SLA. Studies in Second Language Acquisition 32(2), 169-179.

Sheen, Y. (2010b). Differential effects of oral and written corrective feedback in the ESL classroom. Studies in Second Language Acquisition 32(2), 201-234.

Sheen, Y., Wright, D., \& Moldawa, A. (2009). Differential effects of focused and unfocused written correction on the accurate use of grammatical forms by adult ESL learners. System 37(4), 556569.

Sheppard, K. (1992). Two feedback types: Do they make a difference? RELC Journal 23(1), 103-110.

Skehan, P. (1998). A cognitive approach to language learning. Oxford: Oxford University Press.

Skehan, P., \& Foster, P. (2001). Cognition and tasks. In P. Robinson (Ed.), Cognition and second language instruction (pp. 183-205). Cambridge: Cambridge University Press.

Storch, N., \& Wigglesworth, G. (2010). Learners' processing, uptake, and retention of corrective feedback on writing: Case studies. Studies in Second Language Acquisition 32(2), 303-334.

Svalberg, A. M-L. (2007). Language awareness and language learning. Language Teaching 40(4), 287-308.

Swain, M. (1985). Communicative competence: Some roles of comprehensible input and comprehensible output in its development. In S. M. Gass \& C. G. Madden (Eds.), Input in second language acquisition (pp. 235-253). Rowley, MA: Newbury House.

Swain, M. (1991). French immersion and its offshoots: Getting two for one. In B. Freed (Ed.), Foreign language acquisition: Research and the classroom (pp. 91-103). Lexington, MA: Heath.

Swain, M. (1995). Three functions of output in second language learning. In G. Cook \& B. Seidlhofer (Eds.), Principle and practice in applied linguistics: Studies in honor of H. G. Widdowson (pp. 125-144). Oxford: Oxford University Press.

Swain, M., \& Lapkin, S. (2002). Talking it through: Two French immersion learners' response to reformulation. International Journal of Educational Research 37(3-4), 285-304.

Tomlin, R. S., \& Villa, V. (1994). Attention in cognitive science and SLA. Studies in Second Language Acquisition 16(2), 183-203.

Truscott, J. (1996). The case against grammar correction in L2 writing classes. Language Learning 46(2), 327-369.

Truscott, J. (1999). The case for "The case against grammar correction in L2 writing classes": A Response to Ferris. Journal of Second Language Writing 8(2), 111-122.

Truscott, J. (2001). Selecting Errors for Selective Error Correction. Concentric: Studies in English Literature and Linguistics 27(2), 93-108.

Truscott, J. (2004). Evidence and conjecture on the effects of correction: A response to Chandler. Journal of Second Language Writing 13(4), 337-343.

Truscott, J. (2007). The effect of error correction on learners' ability to write accurately. Journal of Second Language Writing 16(4), 255-272.

Truscott, J. (2009). Arguments and appearances: A response to Chandler. Journal of Second Language Writing 19(1), 59-60.

Truscott, J. (2010). Some thoughts on Anthony Bruton's critique of the correction debate. System 38(2), 329-335.

Truscott, J., \& Hsu, A. Y.-p. (2008). Error correction, revision, and learning. Journal of Second Language Writing, 17(4), 292-305. 
Van Beuningen, C. G., De Jong, N. H., \& Kuiken, F. (2008). The effect of direct and indirect corrective feedback on L2 learners' written accuracy. ITL International Journal of Applied Linguistics 156, 279-296.

Van Beuningen, C. G., De Jong, N. H., \& Kuiken, F. (accepted for publication). The effect of direct and indirect corrective feedback on L2 learners' written accuracy. Language Learning.

VanPatten, B., \& Cadierno, T. (1993). Explicit instruction and input processing. Studies in Second Language Acquisition 15(2), 225-244.

Yuan, F., \& Ellis, R. (2003). The effects of pre-task planning and on-line planning on fluency, complexity and accuracy in L2 oral production. Applied Linguistics 24(1), 1-27.

$\mathrm{Xu}, \mathrm{C}$. (2009). Overgeneralization from a narrow focus: A response to Ellis et al. (2008) and Bitchener (2008). Journal of Second Language Writing, 18(4), 270-275. 